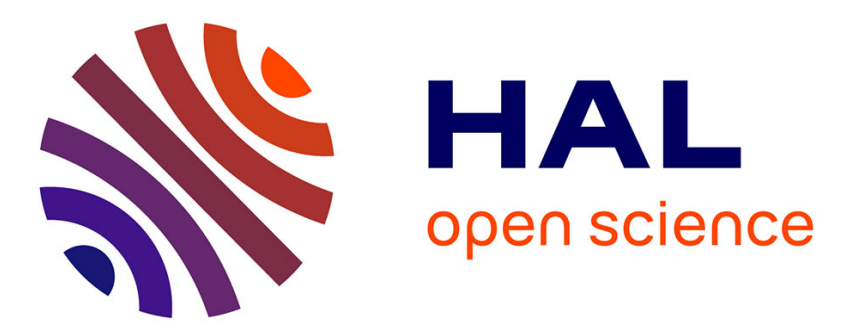

\title{
The mind-body problem and the role of pain: cross-fire between Leibniz and his Cartesian readers
}

Raphaële Andrault

\section{To cite this version:}

Raphaële Andrault. The mind-body problem and the role of pain: cross-fire between Leibniz and his Cartesian readers. British Journal for the History of Philosophy, 2018, 26 ( ${ }^{\circ} 1$ ), pp.25-45. 10.1080/09608788.2017.1379002 . halshs-01616148

\section{HAL Id: halshs-01616148 \\ https://shs.hal.science/halshs-01616148}

Submitted on 5 Oct 2021

HAL is a multi-disciplinary open access archive for the deposit and dissemination of scientific research documents, whether they are published or not. The documents may come from teaching and research institutions in France or abroad, or from public or private research centers.
L'archive ouverte pluridisciplinaire HAL, est destinée au dépôt et à la diffusion de documents scientifiques de niveau recherche, publiés ou non, émanant des établissements d'enseignement et de recherche français ou étrangers, des laboratoires publics ou privés. 


\title{
The mind-body problem and the role of pain Cross-Fire Between Leibniz and his Cartesian Readers
}

\begin{abstract}
This article is about the exchanges between Leibniz, Arnauld, Bayle and Lamy on the subject of pain. The inability of Leibniz's system to account for the phenomenon of pain is a recurring objection of Leibniz's seventeenth-century Cartesian readers to his hypothesis of pre-established harmony: according to them, the spontaneity of the soul and its representative nature cannot account for the affective component of pain. Strikingly enough, this problem has almost never been addressed in Leibniz studies, or only incidentally, through the more general problem of evil. My purpose in this article is to clarify Leibniz's psychophysical parallelism by opposing his representationist account of pain to the functionalist account endorsed by Arnauld, Bayle, Lamy and Malebranche.
\end{abstract}

KEYWORDS: Pain; Leibniz; representation; Arnauld; Bayle

ARTICLE HISTORY: Received 21 March 2017; Revised 23 June and 25 August 2017; Accepted 10 September 2017

\section{Introduction}

'Parallelism' is usually considered as an elegant, rational and economical answer to the mindbody problem. According to Leibniz, who developed this position, the body cannot act upon the mind so as to cause a sensory perception or an emotion, nor can the mind act upon the body so as to produce a voluntary motion. The continuous sequence of perceptions, or thoughts, and the continuous sequence of bodily motions are like two parallel series in the sense that they do not interact even though they correspond to each other according to a 'pre-established harmony'. Put schematically, in the Leibnizian world, each substance and soul of the universe represents all the others. With regard to the mind-body problem, this hypothesis implies that if each perception is produced by a perfectly spontaneous soul, it nevertheless represents the motions occurring simultaneously in the body. Conversely, physical motions are

\footnotetext{
* CNRS, IHRIM UMR 5317, ENS de Lyon, France. Contact: raphaele.andrault@ens-lyon.fr
} 
simultaneously represented by perceptions of the mind without truly causing these sensory perceptions.

[p. 26] If commentators have extensively studied the Leibnizian solution to the mind-body problem, they have usually overlooked a recurrent objection that Leibniz's Cartesian readers addressed to his hypothesis of a pre-established harmony: ${ }^{1}$ the problem of pain, or, more exactly, the capacity of the Leibnizian solution to account for the phenomenon of pain. In this article, I examine how this phenomenon is interpreted in Leibniz's exchanges with Arnauld, Bayle, Lamy and Malebranche, who called attention to three difficulties raised by Leibniz's approach to pain: the problem of concomitance between pain and bodily injury; the spontaneity of the soul which is hardly compatible with the unpleasantness of pain; and the difficulty in admitting that pain might be a natural representation of a physical state. In successively analysing these three objections, my purpose is twofold. First, I want to show that for Leibniz's contemporaries, the mind-body problem could not be reduced simply to the issue of causation with which his commentators widely dealt. Second, I want to clarify Leibniz's pre-established harmony by opposing a representational to a functional account of psychophysical phenomena. This opposition will allow me to indicate what was left unexplained by Leibniz's seductive version of parallelism.

\section{Concomitance: Arnauld's objections}

For further clarity, I present chronologically the various objections concerning pain that Leibniz's Cartesian readers addressed to his 'pre-established harmony'. Let us begin with Antoine Arnauld's objections to the Discourse on Metaphysics.

In reality, Arnauld did not read Leibniz's Discourse on Metaphysics, but rather the summaries Leibniz sent to him, along with some explanations. ${ }^{2}$ During the epistolary exchange that followed (1686-1687), Arnauld expressed [p. 27] his perplexity concerning Leibniz's 'hypothesis of the concomitance and of [the mutual agreement] between substances' by which Leibniz claimed 'that one must explain what happens in the union of soul and body' (Sept. 1686, A II ii 95, trans. LA 78). Arnauld's first example of his own difficulty in understanding

\footnotetext{
${ }^{1}$ By 'Cartesians' I refer only to those French philosophers who, in the late 17th century, developed Descartes' metaphysics in new directions (and particularly in an occasionalist one). I use the term as a convenient label.

${ }^{2}$ I use the following abbreviations for Leibniz's work: A = Sämtliche Schriften und Briefe, edited by the Deutsche Akademie der Wissenschaften, 1923-, cited by series, volume and page number; Dutens = Opera omnia, edited by L. Dutens, cited by volume, tome and page number (1768); GP = Die philosophischen Schriften, edited by C. I. Gerhardt, 1875-90, reprinted in 1965, cited by volume and page number; L $=$ Gottfried Wilhelm Leibniz: Philosophical Papers and Letters, edited and translated by L. E. Loemker, 1969; LA = The Leibniz-Arnauld Correspondence, translated by H. T. Mason, 1967 - I use this translation, rather than the one recently published by Stephan Voss in the Yale Leibniz Studies (2016), because it seems to me closer to the original syntax; $\mathrm{T}=$ Theodicy, translated by E. M. Huggard, 1985; NE = New Essays on Human Understanding, translated by P. Remnant and J. Bennett, 1996; NS = Leibniz's 'New System' and Associated Contemporary Texts, translated by R. S. Woolhouse and R. Francks, 1997. For Descartes, AT = Euvres, edited by C. Adam and P. Tannery, 196474. For Arnauld, Examination = Examen d'un Ecrit qui a pour titre: Traité de l'essence du corps, et de l'union de l'âme avec le corps contre la philosophie de M. Descartes (1680), in Euvres de Messire Antoine Arnauld, tome trente-huitième, edited by G. Du Pac de Bellegarde and J. Hautefage, 1780, 89-176. For Malebranche, ST = The Search after Truth, translated by T. Lennon and P. Olscamp, 1997 (orig. La recherche de la vérité, in Euvres I, edited by G. Rodis-Lewis and G. Malbreil, 1979).
} 
Leibniz's position is the problem of pain: ${ }^{3}$ in denying that pain may be directly caused by a physical injury, as Descartes thinks, or produced by God on the occasion of this injury, following the Occasionalist position, Leibniz's view would imply that the soul creates its own pain. Arnauld highlights one problematic consequence of this view: the soul would 'know that its body is indisposed before being sad about it: whereas it appears that it is the pain which warns it that its body is indisposed' (A II ii 95, trans. LA 79). ${ }^{4}$ Since pain is what warns the soul that its body is injured, pain has to precede the knowledge that something bad has occurred in the body. Consequently, the feeling of pain cannot be reduced to the mental representation of the prick in my arm. This objection concerning the concomitance between soul's pain and body's wound is repeated in the later letter of March 1687:

'I do not clearly understand what you mean by this 'more distinct expression that our soul bears of what is happening now that concerns its body', and how that can bring it about that when my finger is pricked my soul knows of this prick before it feels pain from it.'

(Arnauld to Leibniz, A II ii 151, trans. LA 105)

Arnauld does not really understand what 'to express' means when Leibniz writes that the 'soul expresses more distinctly what is happening in its body'. If it means to have a representation or a distinct knowledge of something, how may Leibniz hold that the soul 'expresses' the state of its own body? Experience shows us every day that we do not know what really occurs in our body. For instance, we have neither the idea nor the sensory perception of the motions of the lymph (Arnauld to Leibniz, August 1687, A II ii, 221, trans. LA 132). Conversely, the feelings and sensory perceptions that we do have can hardly be considered as clear representations of the current state of our body, and through it, of the universe: feeling pain is by no means similar to having the physiological notion of the state of our nervous fibres. Admittedly, our feelings warn us, and eventually may generate some knowledge about our body and the bodies that surround it. But in this case, the knowledge is the result of the feeling, not the feeling itself. Therefore one cannot reduce our feelings to 'representations' of what occurs concomitantly in our body: to know and to feel ('ressentir') are two different things.

[p. 28] If Leibniz does define the 'expression' as a 'representation', he however does not consider that a representation is necessarily a conscious thought or knowledge, as Arnauld assumed: the representation can be unnoticed and very obscure. Both feeling and judgement are actually representations, even though their phenomenal aspects are different. In his answer to Arnauld, Leibniz simply insists on the concomitance between pain (a mental state) and the prick in the arm (a physical state), and on the representational relation between both: pain is the representation of the prick in my arm, but a very confused one, which may eventually develop itself into a clear and distinctive representation of what is happening to my body. This

\footnotetext{
${ }^{3}$ R. Sleigh (1990, 147-50) alludes to Arnauld's objections on pain, but he analyses them by means of conceptual analysis as one example among others of psychophysical causation.

${ }^{4}$ Arnauld compares this position to Augustine's definition of pain in the City of God. See Pariente (1994, 203-4), who is to my knowledge the only commentator to deal with the problem of pain for Leibniz's 'hypothesis of concomitance'.
} 
development from confused feeling toward distinct thought does not contradict the general concomitance between mental and physical states:

'states of the souls are naturally and essentially expressions of the corresponding states of the world, and particularly of the bodies which then belong to them; therefore, since the prick forms part of the state of the body at moment $\mathrm{B}$, the representation or expression of the prick, which is pain, will also form part of the state of the soul at moment B.'

(Leibniz to Arnauld, 9 October 1687, A II ii 243, trans. LA 146)

Nothing, however, indicates that Arnauld was convinced by this answer.

\section{Spontaneity: Bayle's and Lamy's objections}

The second series of objections comes from Bayle and Lamy, and concerns more directly the spontaneity that Leibniz gives to the soul. According to the New System of the Nature and the Communication of Substances and its accompanying Clarifications, published between 1695 and 1696 in the Journal des Sçavans and the Histoire des Ouvrages des Sçavans, 'everything in [the soul] arises from its own nature, with a perfect spontaneity as regards itself, and yet with a perfect conformity to things outside it'. In that way, 'its perceptions or expressions of external things occur in the soul at just the right time in virtue of its own laws, as in a world apart, as if there existed nothing but God and that soul' (GP IV 484, trans. NS 16-7). What Leibniz named the 'hypothesis of concomitance' in his letters to Arnauld is now labelled the 'hypothesis of harmony'. One of Bayle's first objections is the following:

'I cannot understand the series of spontaneous internal actions which could make a dog's soul feel pain immediately after having felt pleasure, even if it were all alone in the universe [...] I also find the spontaneity of this soul wholly incompatible with its feelings of pain, and in general with all feelings it finds unpleasant.'

(Bayle, 1697, Note H to Dictionary Article 'Rorarius', trans. NS 72-3)

[p. 29] Pain is once again the paradigmatic example of the difficulties raised by Leibniz's hypothesis. Six years later, after having read Leibniz's reply, Bayle insists on the same point:

'We could never understand how God might have been able to put into Julius Caesar's soul the principle of a change such as the following: no doubt more than once whilst he was suckling he was pricked by a pin; according to the theory we are examining here, the soul would have had to modify itself with a feeling of pain immediately after the pleasant sensations of the sweetness of milk which it had been having for two or three minutes together.'

(Bayle, 1702, Note L to Dictionary Article 'Rorarius', trans. NS 90) 
Bayle does not refuse the general notion that the soul represents what occurs in the body (GP IV 549, trans. NS 91). He rather discusses how this representative activity is combined with both the simplicity and the spontaneity that Leibniz attributes to the soul. Regarding simplicity, his arguments are the following. First, if the soul is simple and has no parts, as Leibniz claims, the soul should always remain in the same state, or retain the same perception, for there would be no interaction inside or outside the soul that could make it change. Second, if the soul represents the 'innumerable variety of disturbances' to which its body is continually exposed (Bayle, NS 87), as Leibniz assumes, the soul is not a mind, but 'a host of minds', 'analogous to a great apparatus of wheels and springs [...] arranged in accordance with the vicissitudes of our bodily mechanism' (91). Bayle does not object to the notion that the soul has an 'infinite multitude of small indistinguishable feelings', i.e. perceptions that the soul is not aware of (GP IV 523, trans. NS 83). Here, he is only concerned with the compatibility between the representational nature of the soul and its simplicity. For Leibniz, however, the substantial simplicity of the soul is entirely compatible with the synchronic complexity and the diachronic development of its internal states or perceptions. Notably, the soul is endowed with a force, or internal law of development, by which it automatically generates its own perceptions. The second aspect of Bayle's objection regards more specifically the question of pain: why, if the soul spontaneously produces its own perceptions, does it not retain only pleasant ones?

In reality, the spontaneity that Leibniz grants to the soul does not imply that it always acts voluntarily: although it is autonomous, the soul still represents the concomitant state of the world and of its own body. Mental states like pain or, more generally, all confused thoughts may occur 'despite' the soul itself, even if they are not really caused by something outside the soul. Leibniz makes this point clear in his answers to Bayle:

'It is through these [infinite number of confused and entangled perceptions] that [the soul] represents outside bodies, and comes to have distinct thoughts which are unlike the preceding ones, because the bodies which the soul represents have suddenly changed to something which strongly affects its own. So the [p. 30] soul sometimes passes from white to black or from yes to no, without knowing how, or at least involuntarily, for what its confused thoughts and its feelings produce in it we attribute to the body. So we should not be surprised if a man who is stung by some insect when eating jam should, despite himself, pass immediately from pleasure to pain.'

(Leibniz, Unpublished comments on Bayle's Note L, GP IV 546, trans. NS

It may seem surprising to put the feeling of pain and the sensation of blackness on the same level. To be sure, sensory perceptions were at the time not always distinguished semantically from emotions, and even from cognitive reactions to physical feelings. In seventeenth-century French, for example, the term feeling ('sentiment', to which we usually give today an emotional value) on the one hand, and the term sensations ('sensations', which may mean any perception that we are aware of) on the other hand, could equally translate the Latin word 'sensus'.${ }^{5}$ If

\footnotetext{
${ }^{5}$ See Armogathe (1996) about Descartes, and Lamarra (1996) about Leibniz.
} 
Leibniz's correspondents tend to use the French word 'sentiment' more frequently than 'sensation' when referring to pain, Leibniz tends to use more frequently 'sensation' and reserve 'sentiment' to refer to an opinion. But this tendency is by no means systematic. In addition, sensations, feelings, and perceptions were all considered 'thoughts' by the Cartesians. Leibniz, however, goes a step further. He does not make a terminological distinction between 'outer sensations' of colours or sounds that allow us to know certain properties of external objects, and 'inner sensations' of hunger, pain or itches that do not allow for such knowledge. Every sensory perception, as subjective and equivocal as it may appear, represents something outside, be it our own body or the satellites of Saturn. Accordingly, 'the pleasant feeling of moderate heat and the painful feeling of excessive heat are equally representative of the motions of matter'. Painfulness is thus not 'something basic and inexplicable' (Supplement to the Explanation of the New System, GP IV 575, trans. NS 140). It results from the collection of 'small confused perceptions' that individually represent a modification of our body (GP IV 532, trans. NS 76).

Still, Arnauld and Bayle are not the only philosophers to point out the feeling of pain as one of the most obvious obstacles to Leibniz's hypothesis. Later on, François Lamy (16361711) also raises the same objection: ${ }^{6}$

'[T]he author of this system still holds that it is the substances which modify themselves by their own forces and which, by I don't know what spontaneity, produce all the changes and all the thoughts which occur in them [...] If [...] the soul, for example, freely gives itself thoughts, then why does it give itself such disagreeable and painful ones? What pleasure does it find in tormenting itself?'

(Lamy, Fifth Reflections, 1699, NS 145)

[p. 31] A few paragraphs later, Lamy proposes a similar objection:

'What a charming law it would be by which a soul which is engaged in abstract thought about religion, or in contemplating the deity, finds itself gripped by a sharp pain which makes it break off and abandon its train of thought!'

(Lamy, Fifth Reflections, 1699, NS 147)

This qualitative component of pain, what one calls today its pronounced negative valence, explains why Bayle or Lamy mention more often pain - rather than pleasure or sensory perceptions of colour - as a persistent difficulty in Leibniz's position: the unpleasantness of pain seems to indicate that it is provoked in us by an exterior cause or constraint. And this exterior cause would contradict the idea of the spontaneity of the soul assumed by Leibniz. Pain is thus emblematic of the disagreements regarding the causal powers of the soul between the occasionalists, who put all causal efficacy in God, and Leibniz, for whom each substance has a certain immanent power in itself. To be sure, Lamy's reading is not faithful to Leibniz's text on one main point, already emphasized in the reply to Bayle: the spontaneity of the soul should not be understood as complete free will - that is, as the mind's capacity to do or to think

\footnotetext{
${ }^{6}$ For the historical details of Leibniz-Lamy exchanges, see Woolhouse and Franck, NS 132-6.
} 
whatever it wants as if it were all alone in the world. Nevertheless, Lamy's problem is not only epistemic; it is also a moral problem, since aversive feelings like pain or torment apparently demand a justification that pleasant thoughts do not demand:

'what wisdom, and indeed what justice, is there for example in making a soul pass suddenly from joy to pain merely by the laws [...] of its nature, without its having deserved that punishment through some wrongdoing?'

(Lamy, Fifth Reflections, 1699, NS 145)

Pain belongs to those feelings that may be unbearable and that one may interpret as a punishment. A solution to the mind-body problem should thus not only explain pain by ascribing it an efficient cause, but also justify it, by assigning it some usefulness. Leibniz's response focuses, however, on the causal source of confused feelings and the strict correspondence between feelings and physical events: the occurrence of sensations 'is not without cause and without reason, since they happen because the soul must express the body'. Generally speaking, Leibniz does not see why his own system would be more problematic on this point, the source of pain, than Descartes's or Malebranche's (GP IV 479, trans. NS 153). I leave aside here the question of whether Leibniz's solution is objectively more satisfactory than Descartes' or Malebranche's systems. I am interested only in noting that Leibniz's answer is very general: he contents himself with underlining the advantages of the hypothesis of preestablished harmony in terms of intelligibility. He thus invokes the 'reason' of our sensations, the general mechanism that explains their production, but does not explain specifically why we [p. 32] experience some of our perceptions as painful. By contrast, as I will show, Malebranche explains the feeling of pain per se by means of its usefulness for the preservation of our life. It is not the case that, for Leibniz, pain serves no purpose at all. In the Theodicy, for example, he understands our suffering and pain either as punishment for some evil we have perpetrated or as preparation for our future happiness (see $\S 241$, GP VI 262, trans. T 277). ${ }^{7}$ And yet, Leibniz does not invoke divine justice in his response to Lamy. To understand why Leibniz does not assimilate the 'reason' of pain to its ultimate purpose, we must now turn to some passages in the Theodicy that deal with pain.

\section{Natural versus necessary and arbitrary relations}

In the paragraphs 355-6 of the Theodicy, published in 1710, Leibniz returns to his system of pre-established harmony in order to defend the view that the relations between thoughts and bodily motions are natural. To illustrate this position, Leibniz addresses the problem of pain.

For Leibniz, the relations between our thoughts and the corresponding states of the body are natural, in the sense that he perceives them as neither necessary nor arbitrary. First, mindbody relations are not necessary, because they depend upon a divine choice between several possibilities: like everything in the world, psychophysical phenomena are submitted to the laws

\footnotetext{
${ }^{7}$ On this point, and more generally, on the notion of 'natural evil' and 'physical evil' in the Theodicy, see Antognazza, 2014, 121-2.
} 
of general harmony and to the principle of sufficient reason in agreement with God's wisdom. Second, leaving to one side the metaphysical question of the divine choice in creating the real world, relations between mental and physical events are also natural, in the sense that they stem from their respective natures. Their connection is not only a matter of simultaneity explicable by appealing to God's arbitrary action; it is above all a matter of expression. ${ }^{8}$

This last notion has been extensively discussed by Leibniz's commentators. For my purposes, it suffices to refer to Chris Swoyer's study, which shows that the notion of 'expression' always implies the possibility of a 'surrogative reasoning' (1995, 75). According to this notion, $\mathrm{X}$ expresses $\mathrm{Y}$ when certain properties and relations intrinsic to $\mathrm{X}$, i.e. a certain structure defining $\mathrm{X}$, correspond to certain properties and relations intrinsic to $\mathrm{Y}$, in such a way that it is possible to reason about $Y$ by means of what we know about $X$. There is a certain common structure between $\mathrm{X}$ and $\mathrm{Y}$, even if $\mathrm{Y}$ may be expressed by an infinity of different things $\mathrm{V}$, T or $\mathrm{U} .{ }^{9}$ As a result, the association between what expresses one thing and this thing [p. 33] itself cannot be accidental, or purely conventional. As we have seen in Leibniz's exchanges with Arnauld and Bayle, Leibniz often clarifies the meaning of the verb 'express' (exprimer) by its more common equivalent 'represent' (représenter). It is also the case in the Theodicy:

'it is not enough for God to ordain simply that a wound should excite an agreeable sensation: natural means must be found for that purpose. The real means whereby God causes the soul to be conscious of what happens in the body have their origin in the nature of the soul, which represents the bodies and is so made beforehand that the representations which are to spring up one from another within it, by a natural sequence of thoughts, correspond to the changes in the body [...]. [The] representation has a natural relation to that which is to be represented.'

(§ 355-356; GP VI 356, trans. T 339)

Consequently, the sensation of pain represents the small movements in the injured organs as naturally as the idea of the round shape represents the round shape. In this sense, our perceptions depend upon bodies and movements 'in a natural way' - and not upon 'God's good pleasure' (New Essays on Human Understanding, IV, 6, § 7, A VI vi 403, my translation). If, however, the relation between pain and bodily damage is not perceived by us as natural and representational, it is solely because pain is a confused thought, composed of an entangled multiplicity of perceptions that are undifferentiated, not distinguished (non distinguées in French), and unnoticed (inaperçues). Indeed, the nature of 'a sensitive perception' is 'to be and to remain confused'. And even though sensory perceptions in general 'depend upon the detail of figures and movements, and express them exactly, [...] we cannot distinguish this detail in the confusion of the great multitude of small mechanical actions which strike our senses' (ibidem). It is not only the case that we are physiologically unable to perceive all the elements that compose our various feelings, but also that if we were able to perceive those small elements,

\footnotetext{
${ }^{8}$ Leibniz first develops this notion in What is an Idea? (A VI iv 1369, trans. L 207) and the Discourse on Metaphysics (A VI iv 1581, trans. L 308).

${ }^{9}$ Most notably, Swoyer demonstrates that isomorphism is not a necessary condition for expression.
} 
we would no longer have this feeling. A feeling is a subjective experience (a qualia) that is per $s e$ irreducible to the perception of its components. If, for example, one were to perceive each $\operatorname{cog}$ of a slow-moving cog-wheel, one would not have the 'perception of an artificial transparency' produced by the very fast movement of the wheel (ibidem; see Ishiguro, 1990, 64-6). Similarly, the person who feels pain cannot grasp individually the different perceptions which pain is the result of, because if he did, he would not sense pain, i.e. this confused and unpleasant state that warns us of something.

The Leibnizian statement that pain naturally represents bodily injury opposes two conceptions of pain. The first one, endorsed by Bayle, insists on the arbitrariness of the association between pain and what corresponds to it in our body. His reasoning is the following. We are unable to understand the link between certain bodily movements and our own unpleasant feelings [p. 34] as they occur in us (cold, thirst or pain for instance). Accordingly, our reason ascribes to an arbitrary and divine power the responsibility of this unintelligible connection. But still, since this divine power, as divine, is supposed to be beneficial, why did this power not rather associate the action of fire on our hand with a pleasant feeling? Between pain and bodily injury, there is not the same kind of necessary connection that one may observe between the hammer that hits a walnut and the fact that this walnut breaks apart. The connection between pain and bodily injury rather falls under the specific and undecipherable system of the laws of the mind-body union (Reply to the Questions of a Provincial, 1706, II, chap. 84, 166). As arbitrary as it is, this connection is certainly justified from a divine viewpoint, but our own reason cannot conceive anything about it.

Bayle develops this notion of an arbitrary connection partly in response to William King's conceptions on this matter. In his book On the Origin of Evil (1702), King endeavours to account for natural evils, such as pain, disease, and sadness. Concerning pain, King goes so far as to claim that the human being 'must' feel pleasure or suffer from pain in order to be informed in a quick and easy way about what is useful and what is harmful to the body, about what to seek and what to avoid (chap. IV, sect. 4, 62). Such a justification of pain may seem intuitive: after all, if the burning of my hand did not provoke pain, would I immediately take my hand from the fire so as to preserve my body? In a striking passage of The Search after Truth (1674), Malebranche develops exactly this example to account for the confusion and unpleasantness of pain:

'if the soul perceived only what takes place in the hand when it is being burned, if it saw in it only the movement and rupture of fibers, it would hardly take any notice; it might even derive from it some whimsical satisfaction, like those simpletons who amuse themselves by breaking everything in furious orgies of destruction. [...] Hence, it was with great wisdom that the Author of the union of our soul and body ordained that we should feel pain when a change capable of destroying it occurs in the body (as when a needle enters the flesh or fire separates some of its parts), and that we should feel a tickling sensation or a pleasant warmth when this movement is moderate, without perceiving what really happens in our bodies [...].'

$(\mathrm{ST}, \mathrm{I}, 10, \S 5,51-2)$. 
In other words, the confusion and unpleasantness of pain have a practical advantage over any clear and distinctive perception of the bodily cause of our harm: they put us in motion so as to make us preserve ourselves. Today, we would speak of the motivational or imperative aspect of pain to express roughly the same idea: feeling pain is an incentive to do whatever may reduce or stop it. Nevertheless, to acknowledge this motivational component of pain does not imply maintaining that pain is a necessary evil, as [p. 35] King assumes. It is even possible to cast doubt on its usefulness by borrowing Bayle's examples, to wit, what is the usefulness of the pain felt by the dying or by women giving birth (Reply to the Questions, 1706, II, 77, 105)?

Without dwelling on King's and Bayle's different propositions, Leibniz opposes to them his own idea of natural and intelligible relations between sensory perceptions and bodily modifications, certainly chosen by God, but rationally (see Rateau, 2008, 404):

'I also doubt, with M. Bayle, whether pain be necessary in order to warn men of peril. But this writer goes too far [...]: he seems to think that a feeling of pleasure could have the same effect, and that, in order to prevent a child from going too near the fire, God could give him ideas of pleasure in proportion to the distance he kept from it. This expedient does not appear very practicable with regard to all evils, unless a miracle were involved. It is more natural that what if it were too near would cause an evil should cause some foreboding of evil when it is a little less near. Yet I admit that it is possible such a foreboding will be something less than pain, and usually this is the case. Thus it indeed appears that pain is not necessary for causing one to shun present peril [...]. There are also many painful evils the avoidance whereof rests not with us.'

(Theodicy $\S 342$, GP VI 317, trans. T 330)

Leibniz adopts Bayle's general notion that pain is probably neither necessarily nor perhaps always usefully associated with a physical danger. First, the representational connection between mind and body leads Leibniz to associate something less unpleasant than pain with the occurring of a dangerous situation: without really feeling pain, we have some 'confused presentiments' or 'insensible dispositions' representing the proximity of fire or the approaching of the wasp (GP IV 547, trans. NS 102). In a sense, when one really feels pain, the harm is already done, since pain as a noticeable feeling is concomitant with a noticeable injury, not with its first signs. Pain and discomfort themselves are thus 'not necessary for causing one to shun present peril' (Theodicy $\S 342$, GP VI 317, trans. T 330) - painless presentiments and dispositions would suffice for this purpose. Second, Leibniz agrees also with Bayle on the conceivability of another kind of association between sensations and bodily modifications. We could indeed conceive something like what the novelist Cyrano de Bergerac depicts in The States and Empires of the Sun frequently referenced by Leibniz: some fictional creatures who never feel pain and have no need for pain to preserve their life. But conceivability does not mean reality: 'after all, these animals are not men [...]; and God's plan ensured that there should not be lacking here on earth a rational animal clothed in flesh and bones, whose structure involves susceptibility to pain' (Theodicy, § 343, GP VI 318, trans. T 331). Setting aside counterfactual arguments, Leibniz declines to consider the possibility that psychophysical phenomena obey a specific and undecipherable code associating them with each other. Such a 
special system would thwart the uniformity of nature. Therefore, it would not be [p. 34] the best, and God could not have chosen it. God does not ordain simply 'by an arbitrary institution' that 'wounds in the body should cause pain in the soul which is united to this body'. This association between bodily modifications and feelings is grounded in the appeal to those 'natural means' that best fit the wisdom of God ( $\$ 354-5$, GP VI 325-6, trans. T 338-9).

Now we can understand why Leibniz does not explain pain by its ultimate usefulness in the exchange with Lamy. For Leibniz, the 'reason' of pain is neither God's specific decision, nor the usefulness of pain for self-preservation. The reason that explains our sensations is the general system of nature, not their particular function. Providing a specific justification of pain would weaken the notion that the representational relation between perceptions and motions is always 'natural' and, as such, in accordance with divine wisdom.

\section{Representationist versus functionalist accounts of pain}

Focusing on the correspondence with Arnauld, Jean-Claude Pariente considers that this very problem of pain 'brings under scrutiny two anthropologies and two theologies that are fundamentally different' $(1994,214)$. Indeed, far from being anecdotal, pain reveals major philosophical issues, both epistemological (is it possible to rationally account for sensory perceptions or not?), moral (how do we have to deal with unpleasant feelings occurring in us?), pragmatic (what does motivate more efficiently an action: psychophysical emotion or distinct knowledge?), and theological (how do we have to understand God's goodness and God's reason?). For Arnauld, faithful to Descartes's Sixth Metaphysical Meditation, the principal function of pain is psychophysical:

'the pain is instituted by the Author of nature to get the soul to watch over the conservation of the body united to it, in such a way as to convince us that God wants us to look upon our body as part of ourselves'

(Arnauld, Examination, 141, trans. Pariente, 1994, 205)

The 'inner sense' of pain is a paradigmatic effect of the 'union' of the soul and the body. It makes this body a body that is really ours, a body from which our mind cannot be separated and which the mind does not consider as a sailor considers his ship (Descartes, AT VII 81). And yet, as affective components of pain are phenomenally heterogeneous with the physical injuries that occasioned them, the phenomenon of pain perfectly illustrates the fact that the nature of the association between our own perceptions and certain physical motions is obscure: this association is both obvious and unintelligible. To be sure, other sensations such as cold, thirst, or pleasure are also consequences of the mind-body union instituted by God, in the same way as [p. 37] pain is. ${ }^{10}$ But pain is perhaps the feeling attached to the body that affects the mind itself most deeply, and to which the mind cannot remain indifferent. Pain is thus emblematic of our finite human condition: by creating us endowed with a soul and a body, God

\footnotetext{
${ }^{10}$ See Malebranche, ST, I, 10, $\S 5,52$ : 'What has just been said about pain and tickling sensations should be understood to apply generally to all other sensations [...]. We began with these two sensations rather than with the others because these $[\ldots]$ best illustrate my meaning.'
} 
acted perhaps partly for our good but by means that are as obscure as they are unpleasant. As a result, the connection between our feelings and our bodily states may seem completely arbitrary to us, and even unjustifiable, while it is contingent upon God's wisdom.

For Leibniz things are completely different. Pain has no existential privilege over other perceptions or feelings. First, Leibniz generally encourages us not to overestimate the importance of natural evils in our lives (Theodicy $\S 251$, GP VI 267, trans. T 281). ${ }^{11}$ In the New Essays on Human Understanding, he even insists on the physiological function of sensory perceptions of which we are not actually aware. For Leibniz, there is a psychophysical dynamics that produces the same beneficial effects as pain. For example, without being truly painful, an insensitive 'uneasiness' composed of small imperceptible incitements might allow us to avoid what is bad for our body, and in this manner might make us 'enjoy the advantage of evil without experiencing its discomfort' (New Essays, II, 20, § 6, A VI vi 165, my translation). ${ }^{12}$ Second, the explanation of feelings like pain is not incumbent upon philosophy. As Pauline Phemister notes, Leibniz's 'defence of the human intelligibility of mind-body relations' leads him to posit 'the organization of the body as essential' $(2011,89)$. If one wants to account for the way we experience pain, one has to enter the details of physiology and appeal to small irritations of the viscera, since 'every vibration of each and every part of the body is meticulously mapped to a corresponding minute, insensible perception in the soul' (96). To be sure, the 'convergence of human and divine intelligence' (88) presupposed by Leibniz still encounters the obvious limits of our own sense organs: the relations between pain and corresponding bodily changes actually remain partially obscure. Nevertheless, from our human incapacity to grasp our feelings as resembling representations of bodily changes, we cannot conclude that these feelings are intrinsically arbitrary:

'It must not be thought that ideas such as those of colour and pain are arbitrary [...] It is true that pain does not resemble the movement of a pin; but it might [p. 38] thoroughly resemble the motions which the pin causes in our body, and might represent them in the soul; and I have not the least doubt that it does.'

(New Essays, II, 8, 13 and $\S 15$, A VI vi 131-2, trans. NE 131-2)

The opposition between these two conceptions of pain goes far beyond the Leibniz-Arnauld correspondence. This underlies also various arguments exchanged with Bayle on several occasions, the discussion with Lamy, Leibniz's reply to Locke in the New Essays and even some disagreements between Malebranche and Leibniz expressed in notes and marginalia. I am well aware that Arnauld's, Bayle's, Lamy's and even Malebranche's theories of ideas and theodicies are dissimilar (see, for example, Nadler, 2011, 201). If Malebranche develops an 'occasionalist' solution to the mind-body problem, toward which Bayle and Lamy are sympathetic, Arnauld has a more complex view: he, for example, considers the possibility that a spiritual being might cause a corporeal modification (96). Whatever their various propositions on psychophysical causation, however, their own descriptions of pain shed a new and coherent

\footnotetext{
${ }^{11}$ For the opposite view, see Bayle's dictionary article 'Xenophane'('D', 1697, II, 2, 1254).

${ }^{12}$ In the same passage, Leibniz evokes unconscious 'semi-pains' (demi-douleurs), but this terminology is partly misleading: as Leibniz recalls a few lines below, pain is by definition a notable, fully perceived, feeling. About this infra-conscious dynamics, see Phemister, 2005, 250; Rateau, 2008, 625.
} 
light on Leibniz's original position. Most importantly, they highlight several potential problems in Leibniz's system:

1) As a warning of a physical danger or a physiological problem, pain occurs before the representation of the damage itself, and consequently cannot be defined as the representation of this damage (see Arnauld's objections).

2) Pain does not resemble bodily changes that are associated with it, and does not correspond to the knowledge of these changes. ${ }^{13}$ Thus, pain cannot be a spontaneous representation of the soul, i.e. a distinct and voluntary thought that would be necessarily or naturally connected to physical changes (see Arnauld's, Bayle's, and Lamy's objections). ${ }^{14}$

3) Pain is more useful and more powerful for the preservation of our life than a clear representation of bodily damage might be, as Malebranche holds, or even more efficient than pleasure might be, insofar as 'pleasure operates not so strongly on us as pain', as Locke notes in the Essay on Human Understanding (II, 20, § 14, 232). This point does not prevent Malebranche from acknowledging, as Bayle also does systematically, that sufferings are sometimes devoid of any obvious meaning (see Moreau, 1999, 122). Nevertheless, these authors ascribe a very specific role in our practical life to the feeling of pain.

4) Someone may feel pain without really having a lesion somewhere, as Malebranche emphasizes in passages mentioning the experience of phantom-limbs. Leibniz expresses his disagreement with these exact [p. 38] passages, noting in the margin of Malebranche's works that illusions like phantom-limbs are 'rare' and not representative (A VI iv 1827). ${ }^{15}$

We could summarize these opposing views endorsed by Leibniz and his Cartesian readers as the opposition between a representationist and a functionalist account of pain. By 'representationist', I do not mean the 'representationalist' theory according to which the mind knows objects indirectly, through the mediation of representations, a position that has been extensively studied in the context of the late Seventeenth-century philosophy. ${ }^{16}$ The representationist conception of pain holds, instead, that the phenomenal character of pain is reducible to its representational content. Accordingly, pain is no more, and no less, than the sensory representation of tissue damage (Tye, 2005, 101). One of the aims of this definition is to propose a more unified theory of mind in which the important point is the informational and discriminative content of our perceptions. Against the strongest version of this representationist view, a psycho-functional account of pain, such as that of Arnauld, Bayle, Lamy and Malebranche, rather insists on affective aspects that are irreducible to the information provided by the stimuli: the negative valence and motivational force of pain, its so-called 'oomph', is predicated on its role in the motor system (Aydede, 2005, 42-3). ${ }^{17}$ According to this viewpoint, pain as an emotional state is one key element in the adapted reaction of the organism to its

\footnotetext{
${ }^{13}$ See Malebranche's distinction between sadness and pain (ST III, 1, § 3, 201) and Leibniz's annotations (A VI iv 1852). See also Arnauld's Examination (141).

${ }^{14}$ In The Knowledge of the Self, Lamy highlights the idea of an arbitrary connection between feelings and movements (1698, V, 531).

${ }^{15}$ See also 'Lecture, analyse et compte rendu de l'Entretien d'un philosophe chrétien' (in Robinet, 1955, 488). In the margin of this last text, Leibniz notes that some passages about sensory perceptions are written against his own system. Accordingly, even if the Malebranche-Leibniz correspondence does not address directly the problem of pain, there still were some exchanges between them on this point.

${ }^{16}$ See, for example, Cook, 1987, 183 and Nadler, 1989, 113. On Leibniz's opinion on this point in Malebranche, see A II iii 39.

${ }^{17}$ For the possible combination of these positions, see also Clark, 2005, and Bain, 2012.
} 
environment.

Those who criticize the representationist view of pain often insist on the fact that phenomenal qualitative components of pain may be disconnected from the physical states that pain is supposed to represent. According to an example used by Malebranche, we may feel the same pain in a phantom limb as the one that we feel in a real leg. Considering this example, can we then still account for the feeling of pain by reference to its representational content, i.e. a lesion in the leg? There are sensations of pain that keep their usual phenomenal aspects, and most notably their pronounced aversive quality, without being related to tissue damage - the person who really suffers from a phantom pain is not 'wrong', or does not wrongly feel pain.

My purpose is not to comment on the contemporary debates on pain. Those are too complex to address within the scope of this article. [p. 40] Contemporary discussions of pain do, however, allow us to better grasp the opposition between Leibniz and his Cartesian readers. On Leibniz's side, the key notions of 'expression' and 'representation' account for all mental states, as affective, painful or motivating as they might appear. Various degrees of perfection of this expression suffice to distinguish between our thoughts and feelings. Our perceptions sometimes are as clear and distinct as the idea of a round shape. But they may also be clear, or noticeable, and confused. This is the case of pain according to Descartes as well as Leibniz (see New Essays, II, 21, 42, A VI vi 194, trans. NE 194). ${ }^{18}$ Finally, our perceptions are sometimes so confused, small, and diffuse that they remain entirely unnoticed. The uniformity and intelligibility of Leibniz's system depend upon the representational nature of the mind which implies that there are small and unnoticed perceptions - a notion that Cartesians, who generally hold that the mind is (or could be, if attentive) aware of all its perceptions, cannot accept. ${ }^{19}$ As Leibniz notes, what makes his own philosophy so 'easy' is the fact that it conceives unknown things - or the things known only confusedly - on the model of the things that we know distinctly (New Essays, IV, 17, § 16, A VI vi 490, trans. NE 490). Accordingly, the unity and simplicity of his philosophy of mind conditions both its acceptability and explanatory value.

On Arnauld's, Bayle's, Lamy's and Malebranche's side, the important thing about our feelings, and most notably about pain, is not their informational content which is far too confused and equivocal; it is rather the role they play in our practical life: sensations allow us to know everything that is related to our own preservation (see Descartes, AT IX 71). ${ }^{20}$ As mistaken as they may be, in every-day situations feelings and sensations still often make us act for our own good. Although Bayle, for example, casts doubt on the justification of pain through its usefulness, which is not as systematic as King believes, he still assumes that God contingently associates pains with bodily changes, so as to warn us about what is occurring in our body. ${ }^{21}$ The aim of this functionalist view of pain is not so much to explain our various mental states in a unified manner as it is to account for their specific value and subjective

\footnotetext{
${ }^{18}$ Descartes, AT IX 44. But it is worth noting that Leibniz changed Descartes's definitions of those notions. See Meditations on Knowledge, Truth, and Ideas, A VI iv 586, trans. L 291. The notion of clarity, used by Leibniz in the Discourse on Metaphysics (A VI iv 1582, trans. L 318), tends to disappear in later works and to be eclipsed by the notion of distinctiveness (the quality of being 'distingué'). For the distinction between confused perceptions and confused ideas, see Duarte, 2009, 713.

${ }^{19}$ This is however a long-debated issue in the history of Cartesianism (Lamy, for example, acknowledges the existence of 'muted and clandestine thoughts,' 1697, V, 374).

${ }^{20}$ About the role of sensations in Arnauld, see Beyssade, 1995.

${ }^{21}$ Long after Bayle, Kripke will defend the contingent association between mental and brain states through the example of pain $(1972,148)$.
} 
appearances. All the authors cited above maintain that pleasure and pain differ more than in degree, because they have in mind first of all the way we experience those two feelings, not their very similar causes (see [p. 41] Malebranche, ST, 1, 10, § 5, 52). In Bayle's philosophy, like in Lamy's, pain plays a key role in the demonstration of the immateriality and true unity of a perceiving I (see Bayle, 1702, 'Leucippe', E, and Lamy, 1694, I, 342). In my opinion, pain is for them a conscious feeling that cannot be divided into non-painful perceptions.

To be sure, the two notions of a representationist and a functionalist account do not completely do justice to the different conceptions of sensations developed by Leibniz and the group of authors that form his Cartesian readers on this topic. These authors, for example, do not deny that sensory sensations or feelings represent something; they deny that they resemble the things they represent, i.e. that they might allow us to transparently know their properties as if they had an 'absolutely necessary relation' with those things (see Malebranche, ST, V, 1, 338). ${ }^{22}$ In addition to this, these philosophers do not systematically prefer functional teleological explanations of psychophysical phenomena. Nevertheless, they still refer to God's specific and contingent arrangement between perceptions and bodily states when pain is at stake. Conversely, Leibniz's notion of pain seems to differ from the representionist view and come closer to a functionalist one in two respects. First, on several occasions, Leibniz defines pain as the sensation of disharmony ('sensum inconcinnitatis' in the letter to Arnauld, 1671, A II i 280), or a sensation of imperfection (New Essays, II, 21, § 42, A VI vi 194, trans. NE 194), correlated to the erratic vibrations of the membranes of the human body (letter to Michelotti, 1715, Dutens II ii 91). ${ }^{23}$ Second, and more importantly, in Leibniz's philosophy, each perception corresponds to a transition of the mind to a state defined by a lesser or greater degree of expression, notably a lesser or greater distinctness. In this respect, pain is a passion, i.e. a transition to a lesser degree of perfection (see, for example, Discourse on Metaphysics, 15, A VI iv 1554, trans. L 313). Pain is thus not only defined through the specificity of the represented thing (bodily injuries), but also immanently, as the effect of an inner transition. The tendency from one perception to another is precisely an 'appetite', a notion as important in Leibniz's 'pneumatics' as is the notion of 'force' in his physics. In a word, Leibniz does not neglect those motivational aspects of our mental states that are crucially dependent upon the physiological functioning of the human body. Surprisingly enough, however, Leibniz does not recall those functional aspects of his own theory when he replies to Arnauld, Bayle or Lamy on the problem of pain, but prefers insisting on the resemblance, or natural relation, between feelings and physical states. [p. 42] Generally speaking, the representationist account of pain does not prevent Leibniz from admitting that pain is ultimately useful. But this teleological explanation is distinct from the explanation of the representational mechanism that produces our various feelings. The simple fact that Leibniz does not give any specific weight to the feeling of pain and does not seek to justify the painfulness of pain - indicates the originality of his solution to the mind-body problem.

\footnotetext{
${ }^{22}$ This notion of resemblance is very vague. In all cases, however, 'non-resemblance' renders impossible the 'surrogative reasoning' provided by Leibniz's notion of expression. The problem of likeness between ideas and objects is a long-debated issue. See for instance Simmons, 2001, 39. For the disagreement between Arnauld and Bayle on the fact that pleasure has an intentional object as ideas do, see Ryan, 2009, 30.

${ }^{23}$ On the connection between Leibniz's physiology and his philosophy of mind, see Andrault, 2014, 320.
} 


\section{Conclusion}

Pain is a recurring objection addressed to Leibniz's system of pre-established harmony. Commentators have generally ignored the topic and rather focused on the issues of secondary quality sensations, or on the question of conscious awareness. ${ }^{24}$ In Leibnizian studies, pain is most often addressed incidentally through the more general problem of evil, the question of animal pain, or the mind-body problem of which pain is only considered one example among others. There is one obvious reason for this relative lack of interest: pain is not a Leibnizian issue, and Leibniz never gave a comprehensive and coherent description of pain, or of any other feeling that our body seems to induce in us. Physical pain is a problem that Leibniz's hypothesis raises for some of his readers, in what we could call a Cartesian philosophical context. The objections of Arnauld, Bayle or Lamy on this point, as well as Leibniz's annotations to Malebranche's works concerning pain, are however neither trivial nor anecdotal. They outline a philosophical alternative. The feeling of pain is crucial in defending an arbitrary and unintelligible mind-body connection specifically created by a benevolent God. In contrast, the role of pain is minor for Leibniz, who supports the representational and intelligible connection between all our perceptions and all the physical motions that happen in the universe.

Considering Leibniz's solution as a 'representationist' account, in opposition to a 'functionalist' one, may seem trivial. Correlated with the particular question of pain, however, this opposition encourages taking more seriously the criteria according to which Leibniz's contemporaries examined his system. First, solutions to the mind-body problem require a certain agreement on the phenomena that these solutions are supposed to explain. And these phenomena are not valued and depicted similarly by the different authors that we have cited above: if Arnauld, Bayle, Lamy and Malebranche highlight the unpleasant components of our human life, riddled with unfair accidents, diseases and sometimes useful [p. 43] discomforts, Leibniz prefers to minimize those components that are not as pervasive, significant, and frequent as one may believe at first sight. ${ }^{25}$ Second, there is nothing obvious about what constitutes a good philosophical explanation to the mind-body problem. Rationally speaking, Leibniz's parallelist solution is attractive: physical and mental states are systematically related to each other and governed by constant laws; subjective experiences are analytically related to their requisites; all our perceptions are thus related to the objects that they express. This solution is elegantly economical. But for Leibniz's readers, the acceptability of his solution depends also on the plausibility and the accuracy of its descriptions. And pain as we experience it subjectively offers a particularity: it has an aversive value that seems useful for the preservation of our life. An explanation of the mind-body problem that would not take into account this common experience and spontaneous search for justification would miss a fundamental aspect of our mental life. Certainly, in the Theodicy, Leibniz claims that suffering is often a punishment for $\sin -$ and when it is not, it prepares for us a 'greater happiness' ( $\$ 241$, GP VI 262, trans. T

\footnotetext{
${ }^{24}$ A lot of articles have discussed Mc Rae's (1976) and Kulstad's (1983) hypotheses on the relation between the five notions of perception, awareness, consciousness, apperception and reflection, a relation sometimes obscured by the fact that in French 'apercevoir' is a not technical verb (it means 'to notice') in opposition to 'aperception'. The problem is whether a sensation, as conscious, is a second-order perception (a perception of a perception).

${ }^{25}$ This view is consistent with Leibniz's references to his own gout attack in this correspondence (see letter to Remond, June 1715, GP III 644).
} 
276). ${ }^{26}$ But, first, he does not mention this question of divine justice, nor does he refer to the physiological usefulness of pain, when his solution to the mind-body problem is at stake. He rather insists upon the general mechanism that explains all our feelings, that is to say, the natural relation between pain and its physical correlates. Second, and most importantly, he minimizes the qualitative and motivational specificity of pain among our sensations by referring it to its unnoticed components. Consequently, he entirely abandons the Cartesian conception of pain which accounted for its unpleasant confusion by appealing to the contingent, but beneficial, association between our feelings and our bodily modifications.

\section{Acknowledgements}

I am grateful to Mogens Lærke, Layla Roesler and two anonymous referees for their helpful comments and suggestions.

\section{Bibliography}

Andrault, Raphaële. 2014. La vie selon la raison. Physiologie et métaphysique chez Spinoza et Leibniz. Paris: Honoré Champion.

Antognazza, Maria Rosa. 2014. 'Metaphysical Evil Revisited'. In New Essays on Leibniz's Theodicy, edited by L. M. Jorgensen and S. Newlands, 112-34. Oxford: Oxford University Press. [p. 44]

Armogathe, Jean-Robert. 1996. 'Sémantèse de sensus-sens dans le corpus cartésien'. In SensusSensatio, edited by M. L. Bianchi, 233-52. Florence: Leo S. Olschki.

Arnauld, Antoine. 1775-83. Euvres de messire Antoine Arnauld. Edited by G. Du Pac de Bellegarde and J. Hautefage. 38 vols. Paris-Lausanne: Sigismond d'Arnay.

Aydede, Murat. 2005. 'Introduction'. In Pain. New Essays on Its Nature and the Methodology of Its Study. Edited by M. Aydede, 1-58. Cambridge: MIT Press.

Bain, David. 2012. 'What makes pains unpleasant?', Philosophical Studies, 166 (1), 60-89.

Bayle, Pierre. 1697; 1702. Dictionnaire historique et critique. Rotterdam: Reinier Leers.

Bayle, Pierre. 1706. Réponse aux questions d'un Provincial. Tome second. Rotterdam: Reinier Leers.

Beyssade, Jean-Marie. 1995. 'Sensation et idée: le patron rude'. In Antoine Arnauld. Philosophie du langage et de la connaissance. Edited by J. C. Pariente, 133-52. Paris: Vrin, 1995.

Clarke, Austen. 2005. 'Painfulness is not a Quale'. In Pain. New Essays. Edited by A. Aydede, 177-97. Cambridge: MIT Press.

Cook, Monte. 1987. 'Descartes's Alledged Representationalism', History of Philosophy Quarterly, 4 (2), 179-95.

Descartes, René. 1964-1974. Euvres complètes. Edited by B. Rochot and A. Tannery. New edition by the CNRS. Paris: Vrin.

Duarte, Shane. 2009. 'Ideas and Confusion in Leibniz'. British Journal for the History of

\footnotetext{
${ }^{26}$ As Phemister shows, the justification of pain by sin and moral evils is problematic for animals, which have a soul and are able to feel pain (according to Leibniz, not to the Cartesians). Leibniz's solution partly consists in minimizing the pain felt by animals, which is always 'very slight' $(2016,176)$.
} 
philosophy, 17 (4), 705-33.

Ishiguro, Hidé. 1990. Leibniz's Philosophy of Logic and Language. New York: Cambridge University Press.

King, William, 1702. De Origine Mali. London: B. Tooke.

Kripke, Saul. 1972. Naming and Necessity. Cambridge: Harvard University Press.

Kulstad, Mark. 1983. 'Leibniz on Consciousness and Reflection'. The Southern Journal of Philosophy, vol. 21 supplement, 39-65.

Lamarra, Antonio. 1996. 'Sens e Sensation nei Nouveaux Essais sur l'entendement humain di Leibniz'. In Sensus-Sensatio, edited by M. L. Bianchi, 309-326. Florence: Leo S. Olschki.

Lamy, François. 1694-1699. De la connoissance de soy-mesme. 5 vols. Paris: A. Pralard.

Leibniz, Gottfried Wilhelm. 1768. Opera omnia. Edited by L. Dutens. 2 vols. Geneva: Fratres de Tournes. [Dutens]

Leibniz, Gottfried Wilhelm. 1923-. Sämtliche Schriften und Briefe. Series I-VIII. Edited by the Deutsche Akademie der Wissenschaften. Berlin: Akademie Verlag. [A]

Leibniz, Gottfried Wilhelm. 1965. Die philosophischen Schriften von Gottfried Wilhelm Leibniz. Edited by C. I. Gerhardt. 7 vols. Berlin: Weidman, 1875-90. Reprinted Hildesheim: Olms. [GP]

Leibniz, Gottfried Wilhelm. 1967. The Leibniz-Arnauld Correspondence. Edited and Translated by H. T Mason, with an introduction by G. H. R. Parkinson. Manchester: Manchester University Press. [LA]

Leibniz, Gottfried Wilhelm. 1969. Gottfried Wilhelm Leibniz: Philosophical Papers and Letters. Edited and translated by L. E. Loemker. $2^{\text {nd }}$ ed. Dordrecht: Reidel. [L]

Leibniz, Gottfried Wilhelm. 1985. Theodicy. Essays on the Goodness of God, the Freedom of Man and the Origin of Evil. Edited by A. Farrer and translated by E. M. Huggard. LaSalle (IL): Open Court. [T]

Leibniz, Gottfried Wilhelm. 1996. New Essays on Human Understanding. Translated by P. Remnant and J. Bennett. $2^{\text {nd }}$ ed. Cambridge: Cambridge University Press. [NE] [p. 45]

Leibniz, Gottfried Wilhelm. 1997. Leibniz's 'New System' and Associated Contemporary Texts. Translated and edited by R. S. Woolhouse and R. Francks. Oxford: Clarendon Press. [NS] Locke, John. 1979. An Essay concerning Human Understanding. Edited by P. H. Nidditch. Oxford: Oxford University Press.

Malebranche, Nicolas. 1979. Euvres I. Edited by G. Rodis-Lewis and G. Malbreil. Paris: Gallimard.

Malebranche, Nicolas. 1997. The Search after Truth. Edited and translated by T. Lennon and P. Olscamp. Cambridge: Cambridge University Press. [ST]

McRae. 1976. Leibniz: Perception, Apperception and Thought. Toronto: University of Toronto Press.

Moreau, Denis. 1999. Deux cartésiens. La polémique Arnauld-Malebranche. Paris: Vrin.

Nadler, Steven. 1989. Arnauld and the Cartesian Philosophy of Ideas. Manchester: Manchester University Press.

Nadler, Steven. 2011. Occasionalism. Causation Among the Cartesians. Oxford: Oxford University Press. Reprinted in 2012.

Pariente, Jean-Claude. 1994. 'The Problem of Pain: a Misunderstanding Between Arnauld and Leibniz,'. In The Great Arnauld and Some of His Philosophical Correspondents, 202-15. 
Edited by E J. Kremer. Toronto: University of Toronto Press.

Phemister, Pauline. 2005. Leibniz and the Natural World. Activity, Passivity and Corporeal Substances in Leibniz s Philosophy. Dordrecht: Springer.

Phemister, Pauline. 2011. 'Are Mind-Body Relations Natural and Intelligible?: Some Early Modern Perspectives'. In Causation and Modern Philosophy, 87-103. Edited by K. Allen and T. Stoneham. London: Routledge.

Phemister, Pauline. 2016. 'Malebranche and Leibniz on the Animals'. In Animals. New Essays. Edited by Andreas Blank, 161-79. Munich: Philosophia.

Rateau, Paul. 2008. La question du mal chez Leibniz. Paris: Honoré Champion.

Robinet, André. 1955. Malebranche et Leibniz. Relations personnelles, présentées avec les textes complets des auteurs et de leurs correspondants. Edited by A. Robinet. Paris: Vrin.

Ryan, Todd. 2009. Bayle's Cartesian Metaphysics. Rediscovering Early Modern Philosophy. New York: Routledge.

Simmons, Alison. 2001. 'Changing the Cartesian Mind: Leibniz on Sensation, Representation and Consciousness'. Philosophical Review, 110 (1), 31-75.

Sleigh, Robert C. 1990. Leibniz \& Arnauld. A Commentary on their Correspondence, New Haven: Yale University Press.

Swoyer, Chris. 1995. 'Leibnizian Expression'. Journal of the History of Philosophy, 33 (1), 6599.

Tye, Michael. 2005. 'Another Look at Representationalism about Pain'. In Pain. New Essays. Edited by M. Aydede, 99-120. Harvard: MIT Press. 